\title{
Subclinical Hypothyroidism in Obese Patients in Rural General Hospital
}

\author{
Anjaneya Prasad $\mathrm{V}^{1}$ Lalitha $\mathrm{P}^{2}$ Pradeep babu $\mathrm{K} \mathrm{V}^{3}$ \\ 1. Dr.Anjaneya Prasad Velivala, Associate Professor, Department of Internal Medicine, Dr.PSIMS\&RF, \\ Chinoutpally, Gannavaram Mandal, Krishna District, Andhra Pradesh. INDIA. 521286 \\ 2. Dr.Lalitha Paladugu, Assistant Professor Department of Internal Medicine,Dr.Psims\&RF \\ 3. Dr.Venkata Pradeep Babu Koyyala, Resident, Department of Internal Medicine,Dr.PSIMS\&RF
}

\begin{abstract}
OBJECTIVE: Sub clinical hypothyroidism is an elevation in serum thyroid stimulating hormone (TSH) with normal serum free thyroxine $\left(F T_{4}\right)$ and tri iodo thyronine ( $F T_{3}$ levels). The purpose of this prospective observational study was to relate subclinical hypothyroidism to obesity.

Method: This study took place at the Department of Medicine, DR. PSIMS \& RF foundation Chinaoutpalli, A.P.India between July 2011 to Dec 2012. 200 patients (100 females, 100 males) between 30 to 60 years of age were included in the study. The normal TSH reference range was 0.4-4.5 $\mu \mathrm{g} / \mathrm{ml}$.
\end{abstract}

Results: TSH levels were significantly higher in morbidly obese patients and in females than in male patients Key words: Subclinical hypothyroidism, obesity, BMI.

\section{Introduction:}

Sub Clinical Hypothyroidism is a condition in which the function of thyroid gland is mildly low with either minimal symptoms or no symptoms of hypothyroidism (1-3). When the thyroid function is decreased, the TSH is increased because of the pituitary release. Subclinical hypothyroidism is characterized by elevated serum thyrotropin (TSH) level, with normal serum free thyrosine (FT4) and tri iodo thyronine (FT ${ }_{3}$ ) levels. Sub clinical hypothyroidism is a risk factor for coronary events, increased cholesterol levels, increased rates of congestive heart failure. The diagnosis is based upon biochemical testing (4) which is done by chemiluminiscence method. The normal TSH range is $0.4-4.5 \mathrm{MIU} / \mathrm{L}$ TSH. Wide variations in TSH level were seen in different individuals with ethnic origin, age, health status and body mass index (BMI). A recent study found that TSH secretioin depends on age in women and is gender invariant.

Thyroid dysfunction is usually associated with body weight and subclinical hypothyroidism is more frequently associated with weight gain ${ }^{(5)}$ The association between thyroid hormones and resting energy expenditure is well established and an inverse relationship between obesity and resting energy expenditure (REE) is also known. REE depends on obligation and adaptive thermogenesis which is under control of $\mathrm{T}_{3}$ and thyroid hormone ${ }^{(6) .}$

Thyroid hormone induces changes in physical activity and in turn to the body mass and the TSH levels usually correlate with body weight ${ }^{7,8,9}$. The elevated TSH concentration in obese individuals is due to a neuroendocrine dysfunction caused by deregulation of the hypothalamo pituitary axis ${ }^{10}$. A person is considered above when his or her weight is $20 \%$ or more above the normal weight and the most common measure is body mass index, which is the ratio of weight of person in kilograms to square of the height in meter square. For a give height BMI is proportional to mass of the body. A BMI of less than 18.5 is considered as underweight and a BMI of 18.5 to 25 may indicate optimal weight while BMI between 25-29.9 may indicate the person is overweight. A person is considered obese if his or her BMI is over 30 and is morbidly obese if BMI is greater than $40^{11}$. Our study showed the frequency of subclinical hypothyroidism is more in females and increases with the increase in $\mathrm{BMI}^{12}$.

\section{Methods :}

A total of 200 consecutive patients (females - 100, males-100) were studied from July 2011 to December 2012 were studied in the department of general medicine, Dr. PSIMS \& RF Chinaoutpally. All patients are in 30-60 age group through physical examination was done to all the individuals including height, weight, waist, circumference. Body mass index (BMI) was calculated as weight (Kg) divided by height in meter $^{2}$. Thyroid function tests were carried out by chemiluminiscence (CLIA) method and the reference values in our laboratory were TSH : $0.4-4.5 \mu \mathrm{IU} / \mathrm{L}, \mathrm{T}_{3}-0.8-2.0 \mu \mathrm{g} / \mathrm{ml} \mathrm{T} 4-5.13-14.06 \mu \mathrm{g} / \mathrm{dl}$. Patients with hypercortisolism, pituitary pathology, pregnant woman, post thyroidectomy, thyroid carcinoma and who were on drugs like lithium, cordorane were excluded. To compare the frequency of variable among different groups chisquare analysis was used. 


\section{Results :}

The mean BMI in males was $36.226 \pm 4.011$ and in females was $38.472 \pm 4.662(\mathrm{p}=0.0004)$ which showed obesity is more frequent in females, among 100 males mean BMI with $30-40$ was $34.790 \pm 3.005$ $(\mathrm{n}=79)$ and females was $36.175+2.695(\mathrm{n}=73)$ with $\mathrm{p}=0.0033$. Morbid obesity was present in 21 males with mean BMI $41.819 \pm 1.847$ and 27 females with mean BMI $44.681 \pm 2.795(\mathrm{p}=0.0002)$. This difference of BMI among males and females was statistically significant. The mean $\bar{T}_{3}$ among males was $1.2318 \pm 0.36$ and in females was $1.0420 \pm 0.22(\mathrm{p}=0.0001)$ mean $\mathrm{T}_{4}$ among males was higher $(7.2403 \pm 1.08)$ than mean $\mathrm{T}_{4}$ is females $(6.7003 \pm 1.06)$ with $\mathrm{p}=0.0005$. The mean TSH was also compared among males $(3.2879 \pm 1.46)$ with females $(5.2845 \pm 3.09) \mathrm{p}=0.0001$ which was significantly higher. Among 200 patients, 44 patients had mean TSH > 4.5 MIU/L. out of them 12 were males with mean TSH $6.1708 \pm 1.055$ and 32 were females with mean TSH $8.9994 \pm 2.951(p=0.0025)$. Mean TSH was also compared with obese and morbidly obese patient in both males and females. The mean TSH $<4.5 \mathrm{MDU} / \mathrm{L}$ was seen in 156 patients in which 88 were males $(2.8948 \pm$ $1.007)$ and 68 were females $(3.5363 \pm 0.643)$ with $\mathrm{p}$ value $=0.0001 .26$ patients were obese $(\mathrm{BMI} 30-40)$ with TSH > 4.5 MDU/L. Out of them 18 were females (mean TSH 8.5/83 \pm 2.61 ) and 8 were males (mean TSH $6.1262 \pm 1.22)$ and $\mathrm{p}=0.0128$. The mean TSH value among morbidly obese patients $(\mathrm{n}=18)$ was significantly higher among females $(n=14)$ with mean TSH $9.6179 \pm 3.33$ when compared with males $(n=4)$ with mean TSH $6.2600 \pm 0.74$.

Table-1

Sub clinical hypothyroidism in Males and Females

\begin{tabular}{|l|l|l|l|l|}
\hline & \multicolumn{1}{|c|}{$>4.5 \mu \mathrm{IU} / \mathrm{L}$} & $<4.5 \mu \mathrm{IU} / \mathrm{L}$ & Chi square value & P value \\
\hline Males & 12 & 88 & 10.519 & 0.0012 \\
\hline Females & 32 & 68 & & \\
\hline
\end{tabular}

The association between rows (groups) and columns (outcomes) is considered to be very statistically significant.

Table -2

$\mathrm{TSH}>4.5 \mu \mathrm{IU} / \mathrm{L}$ and $<4.5 \mu \mathrm{IU} / \mathrm{L}$ in morbid obesity in males and females

\begin{tabular}{|l|l|l|l|l|}
\hline & \multicolumn{1}{|c|}{$>4.5 \mu \mathrm{IU} / \mathrm{L}$} & \multicolumn{1}{|c|}{$<4.5 \mu \mathrm{IU} / \mathrm{L}$} & Chi square value & P value \\
\hline Males & 4 & 17 & 4.114 & 0.0425 \\
\cline { 1 - 3 } Females & 14 & 13 & & \\
\hline
\end{tabular}

The association between rows (groups) and columns (outcomes) is considered to be very statistically significant.

Table -3

TSH $>4.5 \mu \mathrm{IU} / \mathrm{L}$ and $<4.5 \mu \mathrm{IU} / \mathrm{L}$ in moderate obesity in males and females

\begin{tabular}{|l|l|l|l|l|}
\hline & \multicolumn{1}{|c|}{$>4.5 \mu \mathrm{IU} / \mathrm{L}$} & $<4.5 \mu \mathrm{IU} / \mathrm{L}$ & Chi square value & P value \\
\hline Males & 8 & $71<72$ & 0.0307 \\
\hline Females & 18 & 55 & & \\
\hline
\end{tabular}

The association between rows (groups) and columns (outcomes) is considered to be very statistically significant.

Table -4

Comparison of TSH values in moderate (30-40) and morbid obesity (>40)

\begin{tabular}{|l|l|l|l|l|}
\hline & \multicolumn{1}{|c|}{$>4.5 \mu \mathrm{IU} / \mathrm{L}$} & \multicolumn{1}{|c|}{$<\mu \mathrm{IU} / \mathrm{L}$} & Chi square value & P value \\
\hline $30-40$ & 26 & 126 & 7.694 & 0.0055 \\
\hline$>40$ & 18 & 30 & & \\
\hline
\end{tabular}

The association between rows (groups) and columns (outcomes) is considered to be very statistically significant.

\section{Discussion :}

Sub clinical hypothyroidism is considered when a person has elevated serum TSH levels with normal serum free $\mathrm{T}_{4}$ and $\mathrm{T}_{3}$ levels with minimal or no symptoms of hypothyroidism. Evidence based reviews have recommended routine screening for subclinical hypothyroidism as high TSH level is a risk factor for coronary events, dyslipidemia, overt hypothyroidism and increased rate of congestive heart failure. The prevalence of sub clinical hypothyroidism is higher in females and increases with body weight. Our study showed females are obese than males $(27 \%)$ and the mean TSH was also higher than males with p-0.0001 which was statistically significant. 


\section{References}

[1]. Col NF. Surks ML Daniels GH. Subclinical thyroid disease: clinical applications. JAMA $2004: 291: 239-243$.

[2]. Cooper DS. Clinical practice: subclinical hypothyroidism. N Engl J Med 2001; 345: 260-265.

[3]. Ross DS. Subclinical Hypothyroidism. In : Braverman LE., Utiger RU, editors. Wermer and Ingbar's Thy thyroid. $8^{\text {th }}$ ed. New York: Lippincott, Williams and Wilkins; 200.p.1001-2006.

[4]. LANCET, 2012

[5]. J. Clinical endocrine Med. 90:4019-4024

[6]. Relation of thyroid function to body height: Arch. Int. Med. 2008 165:587-592.

[7]. Reineer T. Obesity and thyroid function. Molcell endocrinology 316:165-171,2010 WHO 200 p.g.

[8]. Roel Fsema F, Pereira AM, veldluis JD, Adriaaunse R Endert E, Filers E, Romiji JA. Thyrotropin secretion profiles are not different in men and woman. J Clinic Endocrinol Met ab 94: 3964-3967, 2009.

[9]. Dall's asta C, Paganelli M, Morabito A, Vedani P, Barbieri M, Paolisso G, folli F, Pontiroli AE. Weight Loss Through Gastric Banding: Effects on TSH and Thyroid Hormones in obese subjects with normal thyroid function. Obesity doi : 10.1038,2009.

[10]. Van den Beld AW, Visser TJ, Feelders RA, Grobbee DE, Lamberts SW. Thyroid hormone concentrations, disease, physical function, and mortality in elderly men. J Clin Endocrinol Metab 90:6403-6409, 2005.

[11]. Moulin de Moraes CM, Mancini MC, de Melo ME, Figueiredo DA, Villares SM, Rascovski A, Zilberstein B, Halpern A. Prevalence of subclinical hypothyroidism in a morbidly obese population and improvement after weight loss induced by Roux-en-Y gastric bypass. Obes Surg 15:1287-1291, 2005.

[12]. Lacobellis G, Ribaudo MC, Zappeterreno A, lannucci CV, Leonetti F. Relationship of thyroid function with body mass index, leptin, insulin sensitivity and adiponectin in euthyroid obese women. Clinic Endocrinol 62:487-491, 2005 